\title{
El conocimiento del otro y la conciencia de $\mathbf{s i}^{*}$
}

\author{
Sajid Alfredo Herrera
}

\section{Resumen}

En este artículo, el autor expone la historia social de las corrientes filosóficas en El Salvador durante el siglo XIX. En torno a estas discusiones, existe un presupuesto interesante que pone al descubierto la falsedad de la autonomía absoluta del pensador y sus ideas con respecto a los procesos sociales, asimismo pone en evidencia el lugar que ocupa el pensamiento dentro del mismo cuerpo social. Este presupuesto intenta demostrar que la filosofía se vincula con los procesos ideológicos y humanos $\mathrm{y}$, por tanto, la historia de las ideas filosóficas debe mostrar las relaciones que guarda con las mentalidades colectivas de cada época.

\section{Introducción}

El desarrollo de las ideas filosóficas en El Salvador durante el siglo XIX queda, sin lugar a dudas, condicionado por una de las etapas más importantes de dicha centuria. Esta etapa a la que estamos aludiendo es el final del período colonial, en donde lo que salta a la vista - sobre todo para aquél que desea sumergirse en las corrientes filosóficas de la época- es una efervescencia de procesos ideológicos contrapuestos que respondían a la dinámica misma de los grupos sociales y a los procesos sociopolíticos y económicos.

El objetivo de este trabajo radica en construir un mapa bajo el cual se puedan observar las líneas más importantes de ese desarrollo. Dicho en otras palabras, mi interés estriba en hacer una historia social de las corrientes filosóficas en nuestro país durante el siglo XIX que tenga como punto de partida el final del régimen colonial. Mucho se ha discutido en torno a cómo debe hacerse una historia de las ideas filosóficas. Naturalmente, no pretendo exponer aquí cuáles han sido las diversas

* La conciencia social ibérica a finales del período colonial salvadoreño en los informes de Pedro Cortés y Larraz y de Antonio Gutiérrez y Ulloa. 
tendencias interpretativas en estos últimos tiempos, pues eso sería un asunto aparte que no tengo intención de abordar en este artículo. Lo que sí quiero dejar subrayado - al menos lo exige la naturaleza del trabajo como una mínima aclaración- es la existencia de un presupuesto sumamente interesante en estas discusiones y que algunas historias de las ideas latinoamericanas lo han recogido y destacado enfáticamente. Dicho presupuesto ha ocasionado un giro significativo a las tradicionales formas de interpretación de la historia filosófica porque, por un lado, pone al descubierto la falsedad de la autonomía absoluta del pensador y sus ideas con respecto a los procesos sociales y, por otro, pone en evidencia el lugar que ocupa el pensamiento dentro del mismo cuerpo social. Este presupuesto se empeña en demostrar que la filosofía tiene un carácter vinculante con los procesos ideológicos y humanos. Es así como, toda historia de las ideas filosóficas no sólo deberá inquirir en los ejercicios académicos realizados por ciertos individuos (con tal de no decantar en un simple relato biográfico o en un deshonroso recuento de hazañas intelectuales), sino también deberá mostrar las relaciones que guarda con las mentalidades colectivas de cada época'.

Desde este punto de vista me interesa mostrar la conciencia social de aquellos grupos que a finales del período colonial salvadoreño intervinieron como los actores principales de los procesos sociopolíticos y económicos. Conciencia social elaborada y defendida por los intelectuales orgánicos de cada grupo y en cuyas elaboraciones fuesen sistemáticas o fragmentarias - vemos circular algunas corrientes filosóficas de particular importancia. Esta tentativa no sólo exige interpretar, como punto de partida, la apoyatura teórica de los movimientos criollos y ladinos salvadoreños, ni meramente las influencias de la ilustración inglesa o francesa que aquéllos recibieron mucho antes del siglo XIX. También exige tener como elemento de herencia y, a la vez, como elemento de contrapeso a la conciencia social ibérica. Digo esto porque se tiende muchas veces a hacer una lectura de la sociedad colonial y con ella el enfrentamiento americano-español, en términos maniqueos, es decir, bajo supuestos terriblemente antagónicos: mientras los americanos representarían la oposición ideológica a un sistema basado en la escolástica, mientras ellos constituirían la civilización frente a la barbarie o simplemente representarian el ideal iluminista, los peninsulares serían todo lo contario. En otras palabras, asistimos a la versión americana de la dicotomía medievales-modernos, oscurantismo-renacimiento, generada en Europa durante la Modernidad.

Da la impresión, en muchas obras de historia, que los grupos americanos "surgieron" de repente con un ropaje ideológico distinto (ilustración francesa, liberalismo inglés) al tradicional y éste sería el que los impulsó a realizar los movimientos independentistas. Pero resulta que ni fueron las ideas ilustradas solas las que los "impulsaron" a dicha empresa — como si se tratasen de autómatas- ni tampoco su modo de asimilar la realidad surgió repentinamente del iluminismo no hispánico. Creo que si bien es cierto que hubo una influencia ilustrada en las élites americanas, ésta siguió los patrones de la ilustración española en su acogida. Una herencia afianzada por más de tres siglos era imposible que se disolviera de la noche a la mañana por la recepción de nuevas ideas, sobre todo si esta herencia era la de la cultura hegemónica.

Cuando se ha hablado de una "Ilustración con Dios" en la América española, sostenida en su mayoría por religiosos, y que por lo mismo evitó la ruptura de los movimientos criollos con la Iglesia durante los procesos independentistas 2 , no se hace la suficiente justicia al problema e, incluso, parecería que se desconoce el fenómeno de la llustración española $o$, tal vez, no se le toma en cuenta. Resulta que dicho fenómeno ideológico va más allá de simples formulismos pero, por otro lado, no ha sido una "Ilustración con Dios" por ser meramente expresión de un grupo de religiosos. Eso sin lugar a dudas. Creo que hace falta - al menos

1. Ver Gramsci A., Antología. Sclección, traducción y notas de Manucl Sacristán, Mćxico: Siglo XXI cditorcs, 1992, pp. 422ss; Roig A. A., "Interrogaciones sobre el pensamiento filosófico" en Zca L., (Comp.), América latina en sus ideas, México: Siglo XXI cdilores, 1993, pp. 46-71; Ccrrutti H., Hacia una metodología de la historia de las ideas (filosóficas) en América Latina, Guadalajara: Universidad de Guadalajara, 1986; Dusscl E., Hisloria de la filosofia y filosofía de la liberación, Bogolá: Editorial Nueva América, 1994, pp. 13ss.

2. Ver Werz N., Pensamiento sociopolítico moderno en América Latina, Caracas: Editorial Nucva Socicdad, 1995, p. 31 . 
en una primera aproximación- caracterizar o esquematizar la herencia ilustrada ibérica, pues ha sido un movimiento ideológico hasta ahora poco abordado por las historias de la época elaboradas en el país. Su profundización será una de las tareas pendientes para la historia del pensamiento en El Salvador.

La historia de las ideas es mucho más compleja de lo que se piensa. No se trata, entonces, de crear muros divisorios en donde se traslapan mundos de vida y, es más, en donde éstos continuan perviviendo. La conciencia social americana que observamos en las postrimerías de la colonia es deudora del mundo ibérico de la época (ilustración española) en la forma de ver, asimilar y responder a las circunstancias: esa amalgama de ideas innovadoras y tradicionales, amalgama entre lo nuevo y antiguo, entre lo secular y lo religioso que caracterizaba a la ilustración ibérica, se patentiza en la cosmovisión americana.

Como se ve, el objetivo de abordar la conciencia social ibérica, es decir, el modo cómo el ibérico se concebía así mismo y cómo concebía a los demás a finales del siglo XVIII y principios del $\mathrm{XIX}$, no es algo que tenga para una historia de las corrientes filosóficas en el país una importancia per se. Tal vez con el informe de Cortés y Gutiérrez no se logre una comprensión completa de la ilustración española. Pero al menos espero que deje en el lector ciertos elementos o caracterizaciones que contribuyan a crearse una imagen global del fenómeno para entender mejor el apartado posterior dedicado a la conciencia social de los criollos y ladinos en la Provincia de San Salvador. Ahora bien, ¿por qué se ha elegido al arzobispo Cortés y al intendente Gutiérrez para recrear a partir de sus escritos la mentalidad ibérica del período tomado como inicio de nuestro trabajo? Se pudieron haber analizado, por ejemplo, ciertos escritos del IV arzobispo de Guatemala, Cayetano Francos y Monroy, quien solicitó al rey la creación de la Sociedad Económica Amigos del País en 1784, mostrando así un incuestionable espíritu ilustrado; o bien, algunos escritos de funcionarios políticos de la Capitanía General, entre otros. Sin embargo, pienso que los informes de Cortés y Gutiérrez tienen una importancia capital para nosotros: todo apunta a que sus documentos representaron la mirada analítica sobre ellos mismos y sobre los demás en las postrimerías del régimen colonial en el actual territorio de El Salvador.

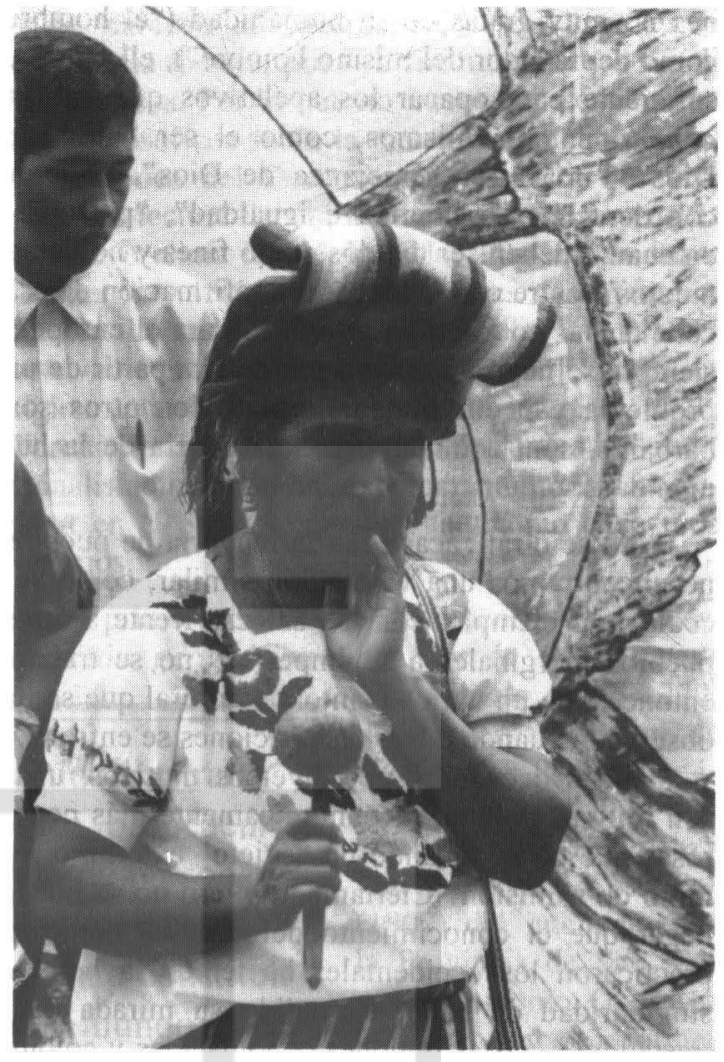

Hay, pues, en ellos no un punto de vista cualquiera sobre los habitantes y la tierra de la Provincia sansalvadoreña, sino una perspectiva de verdaderos intelectuales orgánicos al servicio de los borbones españoles.

\section{Los documentos de Cortés y Gutiérrez bajo el prisma de la ilustración ibérica}

Pese a que la conciencia de los europeos con respecto a sí mismos sufrió muchos reveses a través de su historia, siempre hubo afirmaciones en las que se destacó la singular característica de su humanidad, a su juicio, el ser entes de razón, destinados a ocupar un lugar privilegiado en el mundo y capacitados para la transformación de la naturaleza. La imagen que el europeo tenía de sí como "hombre racional" fue extendiéndose poco a poco desde los estrechos espacios políticosociales de la polis griega, hasta penetrar espacios más abarcantes y de índole religioso, como lo fue la pertenencia a una comunidad de bautizados y creyentes dentro del cristianismo. $Y$ aunque muchas veces esa racionalidad contrastó con otras imáge- 
nes no muy gratas de su humanidad ("el hombre como depredador del mismo hombre"), ello no fue suficiente para opacar los apelativos que habían ganado para sí mismos, como el ser "hijos de Dios", "imagen y semejanza de Dios", "sujetos con derechos de libertad e igualdad", "personas, en cuanto deben ser tenidos como fines y no como medios", entre otros. Llegar a la afirmación de esa conciencia no fue algo arbitrario para el europeo; siempre se llegó a esa imagen de sí a partir de un problema específico de alteridad: los otros son bárbaros, son la inmadurez, la infancia de la humanidad, son una racionalidad incipiente...

Pero se dirá: ¿acaso en la mayoría de pueblos no encontramos una valoración similar, como sucedió, por ejemplo, con los aztecas frente a otros pueblos marginales a su imperio? ¿no se tratará, entonces, de un curioso síntoma cultural que se ha observado cuando dos o más naciones se enfrentan y analizan o cuando, por diversos motivos, unas son militar, política o económicamente más poderosas que otras, creandu un "sujeto" externo o interno de sumisión? Ciertamente. Pero no se puede negar que el conocimiento del otro tal como lo practicaron los occidentales ha tenido la notable singularidad de haber extendido su mirada contrastadora a vastas regiones conquistadas y colonizadas por ellos. En tal situación, circunscribiéndonos al caso particular del mundo europeo, diremos que el conocimiento del otro y la conciencia de sí han sido dos elementos que han constituido sucesivamente lo que a partir de ahora podríamos denominar, en términos generales, como las antropologias europeas o las imágenes que los europeos han tenido de ellos mismos.

Desde el período de la conquista americana, la prolijidad de los discursos sobre el hombre que habitaba estas tierras y su entorno implicó la construcción de una nueva antropología. Una antropología binaria (de vencedores y vencidos) que en principio redujo al "otro" a barbarie y salvajismo para convertirlo, posteriormente, en objeto de guía paternal. Esta "ciencia del hombrè" tuvo su punto de partida, como hemos dicho, en una situación de "alter-ego": frente al otro distinto de mí, en tanto que su peculiaridad es signo de barbarie, se encuentra el convencimiento del europeo de representar y custodiar la racionalidad humana. Ello no era más que una autoconciencia que hundía sus raíces ideológicas en la clásica distinción aristotélica entre los naturalente aptos para dirigir o enseñar y los destinados por naturaleza a obedecer. En ese sentido, el mundo Ibérico poseía la contundente convicción de pertenecer a un ethos no solamente distinto al ethos americano, sino, a un ethos privilegiado por su misma condición étnico-religiosa, el cual funcionó, ideológicamente, como fundamento para el dominio del indígena y de los otros grupos sociales, de tal manera que podían asegurar la prolongación del sistema colonizador. A partir de ese ethos hispánico, la mirada hacia "el otro diferente de mí" dio cabida al análisis, al escrutamiento, a la observación; en última instancia, dio cabida a diversas teorías del conocimiento sobre lo humano, muchas de las cuales eran antagónicas, pero que al fin y al cabo buscaron los procesos de "encauzamiento" del sometido.

El estudio de la "normalidad" y de la "anormalidad" del indígena fue abordado, primero, como una necesidad justificada de despotismo y avasallamiento: su impiedad, sus formas degeneradas de vida, la indigencia, su incapacidad de raciocinio, la inmoralidad de sus costumbres... exigían, desde la óptica peninsular, una condición de sometimiento. Es así como se produjo una jurisprudencia, una pedagogía, una ética y política del conquistado. El conocimiento de esa normalidadanormalidad condujo posteriormente a una serie de saberes antropológicos destinados a un "paternalismo", tal como lo afirmó Francisco de Vitoria en el siglo XVI: "Los indios son hombres, no animales y, por tanto, merecen nuestro respeto; pero son hombres bárbaros a los que hay que proteger como a hijos muy pequeños" 3 . La mentalidad del peninsular, su conciencia de sí o la reafirmación

3. Citado en Gracia D., "El contexto histórico de la bioćtica latinoamericana" en AA.VV. Voluntad de arraigo. Ensayos filosóficos, Managua: UCA, 1994, p. 164. Véasc lambién Zavala S., La defensa de los derechos del hombre en América Latina (s. XVI-XVIII), UNESCO, 1963; Konctzke R., Historia Universal siglo XXI. América Latina. Tomo II: La Epoca Colonial, México: Siglo XXI cditorcs, 1995, p. 30ss.; Montes S., El compadrazgo. Una estructura de poder en El Salvador, San Salvador: UCA Editores, 1979, pp. 80-101. La actitud primera del peninsular frente al indígena fue de sometimiento al "inficl" a través de una "justa guerra". Es indudable que dicha actitud del hispano, que tenía sus raíces en la misma reconquista, cra compartida por la curopa cristiana 
de su humanidad partía, entonces, del contraste entre unos y otros. Sin embargo, esta mirada analítica productora de saberes y de una mentalidad colonial fue más allá: abarcó a las otras capas sociales. La conducta del mismo peninsular y del criollo fueron analizadas; posteriormente las del mestizo y los mulatos. Tanto la intimidad familiar o personal como las formas externas (actividades laborales, indumentarias, vicios, prácticas...) se escrutaron en detalle. Se evidencia, entonces, que la relación primera entre "vencedores-vencidos", peninsulares-indígenas, se tornó múltiple y complicada. Se tornó en una relación de observadores-observados. En correlación con estos estudios antropológicos, la colonia intensificó también aquellos saberes sobre la naturaleza y la economía, sobre todo a finales del siglo XVIII. El afán que primaba fue el aumento $y$ la eficiencia de la productividad como también el mejoramiento de la vida y la "felicidad humana".

En las postrimerías del período colonial salvadoreño encontramos dos documentos que no por tener una finalidad geográfico-religiosa o político-económica son de poca importancia para indagar cuál era la conciencia ibérica y cómo ésta se autoafirmaba a través del conocimiento de los demás. La elaboración y formulación de la conciencia ibérica estuvo, desde el descubrimiento hasta la colonia, a cargo de un reducido grupo de funcionarios eclesiásticos y políticos como, además, de académicos leales a la Corona. Ahora bien, la peculiaridad de tales escritos es doble. Por una parte, carecen de sistematismo para exponer la conciencia ibérica, pues su finalidad no era precisamente esa. Por lo que no intentaban ser dos tratados filosóficos sobre la mentalidad peninsular en plena época del Despotismo llustrado. Por otra parte, su lectura deberá hacerse teniendo en cuenta un nuevo clima ideológico. Un clima cultural que respiraron y legitimaron los autores de ambos informes. Lo cual no implica que hubo una ruptura insalvable entre el pensamiento español que en los siglos anteriores fundamentó los intereses de la Corona desde una perspectiva denominada "tradicionalista" y el expuesto por los autores a considerar en el presente estudio, tal como enseguida veremos.

El primero de dichos documentos es La descripción geográfica-moral de la Diocesis de Goathemala (1768-1770) del tercer arzobispo de Guatemala, Pedro Cortés y Larraz y, el segundo, $E l$ de un minúsculo círculo de personajes, vincia de San Salvador donde se traslapaban elementos antagónicos que llegaron a constituir una particular visión de mundo y que dejó su impronta en tierras americanas. (1807) del intendente de la Provincia de San Salvador, Antonio Gutiérrez y Ulloa. Ambos informes representan los espacios que la sociedad colonial abrió para la mirada; espacios para la mirada que se apoyaban en una variedad de técnicas epistemológicas: los censos, las tasaciones, las descripciones en general, en cuyos casos se exigía minuciosidad y fidelidad a los hechos con tal de descubrir la conducta más intima de los individuos y las riquezas contenidas en estos suelos ${ }^{4}$. Y a pesar de que esa práctica colonial del conocimiento del otro fue precisamente eso,

frente al asedio musulmán. No obstante, las discusiones generadas en la Corte española, en la que participaron teólogos, filósofos y juristas, propiciaron una serie de legislaciones que paulatinamente fue reconociendo la humanidad del indígena y exigía a los peninsulares un tratamiento de carácter "paternal". Entre las legislaciones que podemos mencionar están las "Leyes de Burgos" (1512) y las "Leyes Nuevas" (1542), así como la bula del papa Pablo III, Sublimis Deus (1537), en la que él declaraba la "humanidad" del indígena.

4. Barón Castro nos dice que desde la época de la conquista, la Corona pidió a sus funcionarios "noticias" acerca de los pueblos sometidos. A partir de ese momento, se inicia un proceso de estudio y análisis minucioso, con base en estadísticas y censos, de las poblaciones en América y sus recursos (ver Baron Castro R., La población de El Salvador, San Salvador: UCA Editores, 1978, p. 178ss; tambićn, Konctzke R., op. cit., p. 85ss). En ese contexto hay que ubicar el informe del tercer arzobispo de Guatemala, Pedro Cortés y Laráz, sobre su Diócesis y a la cual pertenecía la Provincia de San Salvador. Por otro lado, el informe del Intendente Gutiérrez y Ulloa responde a la misma estrategia colonial. Uno de los aspectos de las Reformas Borbónicas (ordenanza de 1803) pedía a los corregidores intendentes redactar un informe en el que se describiera la provincia bajo su cargo. (Ver Baron Castro R., op. cit., p. 265ss). Sobre el particular, es interesante lo que nos describe Jorge García Laguardia 
una práctica constante, no se puede pasar por alto, por ningún motivo, que los documentos de los dos funcionarios ya mencionados reflejan la mentalidad propia de su época; es decir, una mentalidad en donde se conjugaban armónicamente las nuevas ideas procedentes del iluminismo europeo con aquellas ideas tradicionalmente españolas en política y fe. Es lo que se ha denominado como el espíritu ilustrado español, que al ser producto de una peculiar historia se caracterizó por una amalgama de lo antiguo con lo nuevo, lo medieval con lo moderno, el tradicionalismo con el progresismo, el barroco con el iluminismo.

La conciencia ilustrada española del siglo XVIII y de las primeras décadas del siglo XIX respondía a una época llena de contrastes e ingredientes opuestos en toda Europa. Nada más que esa conciencia de valores y perspectivas diversas que decantaba la cosmovisión ibérica, guardaba su propia especificidad. Sus exponentes en el siglo XVIII los encontramos en algunas esferas académicas, aristocráticas, profesionales y en algunos funcionarios gubernamentales y eclesiásticos de la dinastía borbónica. No obstante, a finales de la centuria anterior surgieron críticos del orden tradicional e inmovilista, denominados los novatores. Fueron todos ellos quienes absorbieron las "nuevas ideas" con el propósito de sugerir e impulsar un cambio de dirección nacional ante el evidente atraso de la Península con respecto a los demás estados europeos, pero sin avergonzarse de su tradición católica e hispánica. Por su parte, la mayoría de la población, rural o campesina, continuaba con sus prácticas populares y creencias religiosas cargadas de innumerables supersticiones, además de su poca o nula formación académica. Por ello, es explicable que uno de los propósitos de las reformas ilustradas haya gravitado en torno a la educación por considerársele un elemento fundamen- tal, a la par de las reformas económicas, del progreso en el reino.

En tal sentido, la mentalidad hispánico-ilustrada fue una zona ideológica, procedente de un minúsculo círculo de personajes, donde se traslapaban elementos antagónicos que llegaron a constituir una particular visión de mundo y que dejó su impronta en tierras americanas. Lo cual no significó que el pensamiento tradicional "puro" haya desaparecido a tal punto de no haber quedado ningún resquicio de él. Más bien, las corrientes tradicionales y escolásticas continuaron extendiéndose y sus exponentes defendiendo sus propios baluartes teóricos a pesar de las reformas ilustradas realizadas en las universidades durante las últimas décadas del siglo XVIII. Con todo, es factible decir que la pervivencia de algunos rasgos medievales y barrocos, es decir, la pervivencia de una espiritualidad trascendente, la concepción absolutista de Estado, el espíritu de honor e hidalguía, convivieron con ideas reformistas de matices fisiocráticas, con tendencias "jansenistas" y con un pensamiento crítico a las estructuras decadentes. Todo ello y más fue lo peculiar de este complejo ideológico ibérico5 $\mathrm{y}$, sin lugar a dudas, tanto el arzobispo como el intendente manifiestan en sus escritos, en mayor o menor medida, algunos elementos de esa amalgama ideológica que no fue más que la expresión del estamento jerárquico al que ellos pertenecieron. Baste decir que Cortés y Larraz fue propuesto arzobispo de la Diócesis de Guatemala -en 1766 - por Carlos III, el monarca más representativo del Despotismo Ilustrado español; por lo cual no causaría extrañeza que el eclesiástico le rindiera la más abierta fidelidad. Lo mismo puede decirse de Gutiérrez y Ulloa, quien fuese elegido -en 1804 durante la dinastía de Carlos IV para ocupar el cargo de corregidor intendente en la Provincia de San Salvador. Como se ve, ambos represen-

en Orígenes de la democracia constifucional en Centroamérica, San José: EDUCA, 1976: "Los intendentes debían controlar la vagancia, debiendo informarse sobre inclinaciones, vida y costumbres de los Vecinos $y$ Moradores sujetos a su gobierno, pero se recomendaba, sin hacer caso de delaciones infundadas, ni entrometerse a examinar la vida, genio y costumbres domésticas o privadas, que no puedan influir en la tranquilidad, buen exemplo y gobierno público". (pp. 19-20.).

5. Abcllán J. L., Historia crítica del pensamiento español. T. III: Del Barroco a la llustración, Madrid: Espasa Calpe, 1988, pp. 471-489; Domínguez Ortíz A., Sociedad y Estado en el siglo XVIII español, Barcelona: Ariel, 1976, p. 322ss, 429ss, 494; Domínguez Ortíz A., Hechos y figuras del siglo XVIII español, Madrid: Siglo XXI editores, 1973, pp. 121-158; Fraile, G., Historia de la filosofia española. Desde la Ilustración, Madrid: BAC, 1972, pp. 3-8, 66-70; Stoetzer O. C., Las raíces escolásticas de la emancipación de la América española, Madrid: Centro de Estudios Constitucionales, 1982, pp. 114-141; Prieto F., Historia de las ideas y de las formas políticas. T. III: Edad Moderna (2. La Ilustración), Madrid: Unión editorial, 1990, pp. 427-439. 
taron los intereses de la Corona en América. Los intereses de una Corona que había agrupado y formado en torno a ella a un cuerpo selecto de funcionarios o intelectuales orgánicos fieles a la persona del rey y a las nuevas disposiciones reformistas y regalistas.

Pero hay que aclarar, por una parte, que la Ilustración española no fue un conjunto de ideas y disposiciones surgidas de un solo golpe. En los años que median entre el informe de Cortés y el de Gutiérrez había sucedido una serie de medidas reformistas en materia política, economicosocial, religiosa y cultural (la expulsión de los jesuitas del Imperio español, las reformas penales y universitarias, los decretos de comercio libre), mostrando un cuadro inconcluso, con avances o retrocesos en cuanto al reformisno borbónico y su espíritu iluminado se refiere. Tanto es así, que el período en el cual escribe el intendente Gutiérrez y Ulloa (1807) ha sido caracterizado como una época de decadencia del Despotismo llustrado ibérico, en el que el reinado de Carlos IV (1788-1808) no pudo hacer frente a la crisis interna en la Península ni a las variables externas que condicionaban a dicha crisis. Además, la fisonomía ecléctica de ese espíritu iluminista muchas veces no permite dibujar unos contornos bien definidos como se pudiera esperar. La mayoría de obispos elegidos en América durante la segunda mitad del siglo XVIII era ilustrado. Y ello deberá entenderse como una ilustración católica y ecléctica, típicamente española. Por lo mismo, no asombra que a la par de la lectura de autores extranjeros, los funcionarios ilustrados españoles mantenían vivo el pensamiento tradicional (el agustinismo, el tomismo y a algunos pensadores de la Alta Escolástica), no así el pensamiento político de Suárez por considerarlo contrario a los lineamientos borbónicos6. No deberá, entonces, decepcionarnos el hecho de no encontrar en los aspectos por analizar de ambos informes una ilustra- ción muy marcada, pues como ya vimos, sus fronteras entre lo nuevo y lo antiguo fueron imprecisas.

Tres son los puntos que me interesan recalcar en los informes del arzobispo y del intendente. El primero es la concepción antropológica del "otro" y los procesos de su encauzamiento planteadas por Cortés y Larraz; el segundo punto consiste en la visión providencialista hispánica, que presenta tanto Cortés como también Gutiérrez, como una visión en donde covergen elementos religiosos con elementos político-monárquicos; el tercero es la visión utilitaria con la cual fue visto el entorno natural de las posesiones coloniales por parte del intendente. En esos tres puntos veremos cómo, por oposición, el ibero confirma su humanidad frente a los demás grupos sociales.

\section{La concepción antropológica del "otro" y los procesos de su encauzamiento}

Cuando se habla aquí del "otro", básicamente se hará referencia a los indígenas, quienes en la época del arzobispo y del intendente todavía seguían siendo un numeroso grupo de la población. En general, tanto Cortés y Larraz como Gutiérrez y Ulloa coincidieron en los vicios característicos de los ladinos, indios e incluso de algunos españoles (peninsulares y criollos) en la Provincia de San Salvador. Para el arzobispo, los indios eran por naturaleza hipócritas y disimulados aunque los consideraba "hombres racionales"; por su lado, los ladinos eran la fuente de perversión de los indios?. El conocimiento del indígena y del ladino, de sus vidas y creencias, condujo a formular las soluciones para sus vicios. No obstante, las soluciones a las que apuntó el arzobispo con respecto a los indígenas expresaron la transición paulatina de una mentalidad a otra: la transición de una conciencia de arbitrariedad con "aquél" que es diferente y jerárquicamente inferior, a una conciencia de pro-

6. Castañeda Delgado P., "La jerarquía eclesiástica en la América de las Luces” en AA.VV., La América española en la época de las Luces, Madrid: Ediciones de Cultura Hispánica, 1988, pp. 97-119; Abellán J. L., op. cir., pp. 474-476; Pérez J., "Tradición e innovación en América del siglo XVIII" en AA.VV., La América española..., pp. 267-279. Sobre cl recelo a la teoría suaceriana, Joseph Pérez en su artículo citado escribe: "...cl retorno del tomismo sólo ofrece ventajas: es una filosofía sana; es una teoría política menos peligrosa que la de Suárez. Desde 1768, Carlos III recomienda, pues, que de ahora en adelante sólo se utilice en los seminarios manuales conformes a las ideas de San Agustín y de Santo Tomás." (p. 276).

7. Cortés y Larraz P., "Descripción geográfico-moral de la Provincia de San Salvador en la Diócesis de Goathemala" en Colección de documentos importantes relativos a la República de El Salvador, San Salvador: Imprenta Nacional, 1921, pp. 131 y 259. 
tección del otro que es "igual a mí", pero que todavía se encuentra en un estado de inmadurez. Es por eso que para Cortéz y Larraz los indios ya no eran "seres sin alma" - a pesar de la cantidad de males que padecían-, sino más bien, eran "hombres racionales", necesitados de guía paternal para desarrollar sus potencialidades. De ese modo, el arzobispo no era de la opinión del castigo físico como método para corregir la conducta culposa o no culposa de los naturales. Su propuesta era de carácter educativo: nada será mejor para los indígenas que la instrucción y su concentración en colegios a edad temprana para que "no les penetre el sol y los dañe". Y es que, a juicio de Cortés y Larraz, la vida desordenada que llevaban los naturales, dado al mínimo cuidado de sus personas con respecto al clima, los conducía a un deficiente desartollo mental. Lo decía de esta forma: “...ellos desde que nasen se crían desnudos, al sol, al viento, y á todo contra-tiempo, con lo que no pueden dejar de padecer mucha lesion en el cerebro..." 8 .

Lo que de alguna manera deja entrever aquí el prelado $-y$ que no podemos dejar de comentares la creencia en el influjo climatológico sobre el carácter intelectual y moral de los pueblos. La idea de la influencia climatológica en los individuos y las diversas naciones había sido una concepción muy generalizada desde tiempo atrás, hasta tal punto que sirvió en repetidas ocasiones para establecer la inferioridad de unos estados con respecto a otros. En el mismo siglo en el que escribe el arzobispo, Montesquieu, partiendo igualmente de una mirada contrastadora, afimaba lo siguiente: "los pueblos de los países cálidos son tímidos como los ancianos; los de los paises fríos son valientes como los jóvenes.”; “...si nos acercamos a países del sur nos parecerá que nos alejamos de la moral..."9. De ahí que con ese análisis antropológico se estaba aportando un elemento más para el proteccionismo colonizador de estas tierras.

Como vemos, la propuesta del arzobispo partía de una concepción pedagógico-paternalista e igualitaria, en franco rechazo a una concepción de sometimiento despótico que había sido sostenida teóricamente durante mucho tiempo atrás -aunque en la vida cotidiana siguió frecuentándose ese trato a los naturales.

Dicha concepción pedagógico-paternalista e igualitaria tenía sin duda una fuente teórica en la Escolástica española del siglo XVI y otra, procedente del clima cultural contemporáneo al arzobispo. La fuente teórica antigua la podemos remontar, como dijimos, hasta el siglo XVI con la Escuela de Salamanca. Francisco de Vitoria, Diego de Covarrubias, los exalumnos de ambos y las sucesivas generaciones de académicos de la mencionada universidad, configuraron una visión humanística que iba más allá de los contornos europeos. Fueron Vitoria y sus exalumnos quienes elaboraron directa e indirectamente la apoyatura teórica para las Leyes Nuevas de 1542, con la finalidad de proteger a los indígenas de los constantes abusos por parte de los españoles. La idea de proteccionismo o paternalismo educativo representó, según la Escuela de Salamanca, la mejor solución para conseguir el progreso del indio. Su fundamento se encontraba en una "antropología igualitaria" que a partir de ese momento establecía la igualdad entre españoles e indios. Una igualdad que se basaba en la incuestionable humanidad de los naturales y el consecuente reconocimiento de sus atributos como el ser personas, imágenes de Dios, seres libres y racionales. Esta idea del paternalismo salmantino estuvo unida a la idea de un "protectorado político", en el cual los hispánicos estarían en tierras americanas sólo hasta conseguir la etapa plena de madurez.del natural, es

8. Ibid., p. 223.

9. Montcsquicu, Del espíritu de las leyes, Madrid: Tccnos, 1987, pp. 155 y 157. Ver también cl análisis dc Aristótclcs, Ética Nicomaquea. Política, Mćxico: Porrúa, 1989, p. 285. 
decir, cuando hubiese alcanzado su desarrollo y autonomía mediante estrategias netamente educativas. Luego, la abandonarían con la independencia política de éstos últimos 10 .

La otra fuente responde al clima cultural ilustrado del siglo XVIII respirado por Cortés y Larraz y del que se volvió en su portador. La educación y la cultura era para el naciente espíritu ilustrado español lo que la razón era para las demás naciones europeas. Frente a las supersticiones populares, a la escandalosa ignorancia de la mayor parte de la población, a las prácticas y creencias mal fundadas en posiciones acríticas o por la relajación moral de los ciudadanos, se exigía una estrategia educativa que se filtrase a través de las distintas redes sociales y que estuviese dirigida por el Estado. Gaspar Melchor de Jovellanos (1744-1811) sostenía: "Las fuentes de la prosperidad social serán muchas, pero todas nacen de un mismo origen, y este origen es la instrucción pública..."1l Dicha educación debía de favorecer las artes y ciencias útiles con la finalidad de mejorar la agricultura, el comercio y la industria, pues a juicio de los ilustrados españoles, las especulaciones metafísicas de la escolástica y la lógica aristotélica no habían conseguido hasta el momento la prosperidad de la nación. Pero es más, se buscaba que la utilidad educativa hiciera retornar a los españoles a la afamada consigna iluminista de la felicidad humana.

Junto a tales aspiraciones, a mediados del siglo XVIII y en consonancia con el ambiente jurídico de algunos países europeos, se llevaron a cabo estudios, revisiones, discusiones y reformas a la legislación penal española con el objetivo de transformar aquellos procesos punitivos considerados como crueles y degradantes, sustituyéndose por castigos más ejemplares. Esa conciencia insistente de los ilustrados españoles (Feijóo, Jovellanos, Campomanes, Campillo...) por una transformación

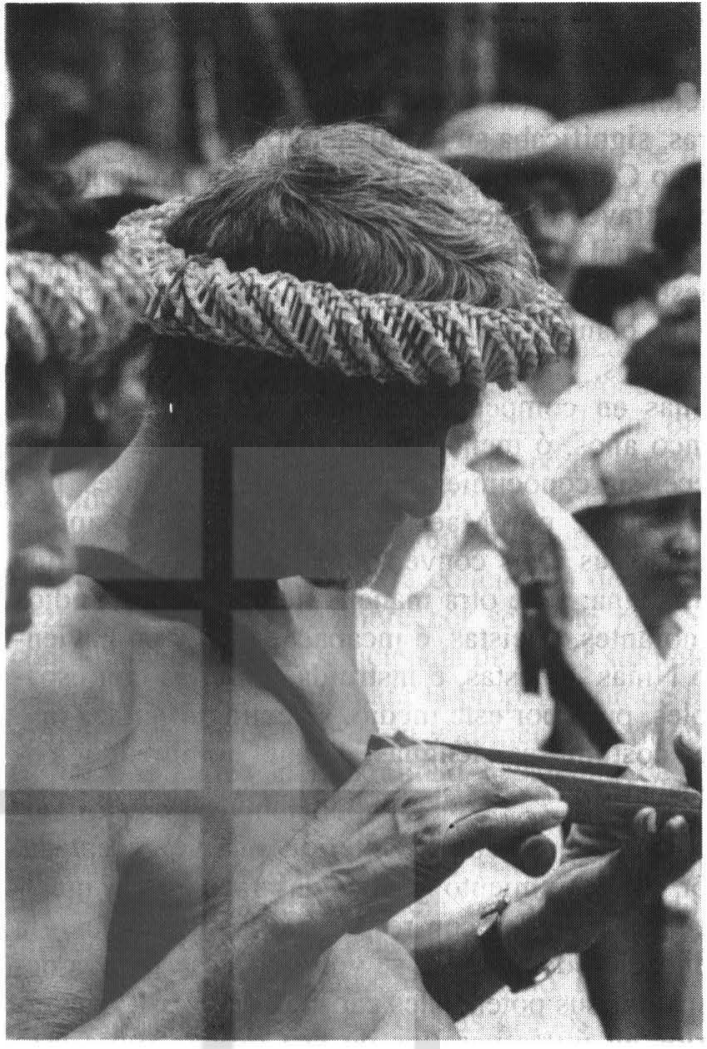

y ampliación del sistema educativo, así como también por un "humanismo en las penas", trajo consigo entre los peninsulares una revalorización del principio pedagógico-paternalista e igualitario para con los americanos. La humanidad del indígena volvió a ser tenida por racional y sus defectos e incapacidades serían solucionados a partir de una asistencia cuidadosa mediante una enseñanza desprovista de tratos crueles. Asi lo mantuvo José Campillo al declarar que en el indígena había "una razón bien puesta, unas potencias claras y una comprehensión, habilidad y aptitud, ni tan bárbara ni aun tan vulgar como se afirma"12.

10. Ver Percña L., La idea de justicia en la conquista de América, Madrid: MAPFRE, 1992, pp. 87-123, 163-191. Algunos de los puntos de las Leyes Nuevas dicen: "Todos los indios de estas partes son iguales como los demás vasallos y súbditos nucstros...”; “...Dios Nucstro Scñor crió los dichos indios libres y no sujetos (...). Los españoles no tendrán poder ni mando alguno para servirse de los indios para gozar de su tributo ni servicio personal" (p. 173ss); ver también Pereña L., "El proceso a la conquista de América" en Robles L. (Coor.), Filosofia iberoamericana en la época del encuentro, Madrid: Edit. Trotta, 1992, pp. 208ss.

11. Cilado por Pricto F., op. cit., p. 475.

12. Citado en Zavala S., op. cit., p. 54. Sobre el pensamiento ilustrado español en torno a la cultura y la “humanización de las penas", ver Abellán J. L., op. cit., p. 473; Sarrailh J., La España ilustrada en la segunda mitad del siglo XVIII, México: FCE, 1974, pp. 55, 157-190, 538-543; Domínguez Orlíz A., Sociedad y Estado..., pp. 330-337. 
Resulta incuestionable que la educación en América implicaba para los indígenas su incorporación al mundo occidental. Dicho en otras palabras, significaba su ladinización. A juicio del arzobispo Cortés y Larraz, la ladinización podía hacerse a través de dos métodos: el proceso educativo -al cual ya hemos aludido- y el proceso de mestizaje mediante los matrimonios interraciales. El lo plantea de la siguiente manera: "establecer Colegios, endonde se encerrarán los Niños, y las Niñas en competente numero, desde la edad de cinco años, ó menos; enlas que havian de permanecer sin conocimiento, ni trato de sus Padres, instruyendose por Maestros Competentes, y aprendiendo las artes convenientes, politica, y doctrina christiana; y de otra manera siempre seran Yndios ignorantes, Ateistas, é incapaces (...), y en haviendo Niñas honestas, é instruidas casarlas con españoles, pues por este medio, se extinguirian las malas costumbres, lenguas, $y$ aun nombre de $\mathrm{Yn}_{\mathrm{n}}$ dios"1.3.

De acuerdo con lo anterior, una vez aceptada, por convencimiento y dilatadas razones, la igualdad del indígena con respecto a los españoles, la educación de aquéllos se volvía necesaria para desarrollar sus potenciales capacidades y así, convertirlos en útiles vasallos de la Corona. Sobre esto ya hemos hablado en las líneas anteriores. Tal vez reste señalar que la idea del prelado - aunque no trabajada lo suficiente- sobre cómo se debía construir una arquitectura educativa, es decir, las disposiciones a adoptar con los sujetos de dicho proceso, la edad adecuada para ingresar a los colegios, las asignaturas a impartir o las cualidades de los maestros, no fue un sentir exclusivamente suyo. Ya en su época se demandó la continuación de políticas en favor de la creación o rehabilitación de colegios, seminarios $\mathrm{e}$ institutos para indígenas, para nobles indígenas o en donde se educasen ellos juntamente con los españoles. Algunas condiciones que menciona Cortés eran muy parecidas a las propuestas por otros obispos y clérigos de América durante la misma centuria: formación desde muy temprana edad, maestros competentes, asignaturas como artes útiles, doctrina cristiana, gramática, etc. Además, ciertos religiosos favore- cieron a muchos naturales con programas de becas para cursar grados superiores 14 .

Sin embargo, hay algo llamativo en la argumentación del prelado. Y es que propone el proceso de mestizaje como una alternativa para la incorporación indiana al mundo occidental. Al parecer, el arzobispo creía que ese otro camino podía ser tan válido como el precedente, pues no se dudaba de la humanidad del indígena, sino de sus costumbres y lenguas. Era la cultura la que se reprochaba, no a los sujetos. Ahora bien, con ese afán de extirpar la sombra de las costumbres viciadas, las propuestas de carácter no educativas variaron de opinión a lo largo de tres siglos de colonia: desde vestirlos y calzarlos a la usanza hispánica, hasta alejar a los infantes indígenas de sus progenitores. La idea del arzobispo en torno a los matrimonios interraciales fue una opinión que desde la época de la conquista, la Corona ni impidió ni favoreció; más bien, todo quedó en sugerencias o desaprobaciones coyunturales procedentes de distintos sectores que dieron margen de libertad a los vasallos para realizarlos o no. Lo importante de este punto es que en dicha sugerencia, Cortés deja esbozado ligeramente la mentalidad sobre la mujer que se tenía en su tiempo.

El conocimiento del otro lanzó su mirada analítica también hacia las mujeres, el grupo menos favorecido entre los naturales y, aún, entre los españoles. Como vimos, Cortés afirmaba que los matrimonios deberían realizarse con aquéllas jóvenes "honestas e intruidas", con lo cual estaba reproduciendo para las indigenas la misma concepción de lo femenino que la sociedad española y los ilustrados españoles compartían en cierto sentido. Una mentalidad nada homogénea en donde ellas eran promovidas, por unos, para una formación que no las convirtiese en objetos pasivos. Pero ese sentimiento contrario a la pasividad se reducía meramente a favorecer la libertad de las jóvenes para elegir su pareja. Otros, la mayoría, las sujetaban al régimen familiar patriarcal y moralista de la época, donde en sus intenciones no se olvidaban de una enseñanza específica que las convirtiese en buenas mujeres de hogar, recordando tal vez la figura literaria de fray Luis de León sobre la "per-

13. Cortés y Larraz P., op. cit., p. 131.

14. Olacchca Labayen J.B., El indigenismo desdeñado. La lucha conira la marginación del indio en la América española, Madrid: MAPFRE, 1992, pp. 147-164, 181-211. 
fecta casada". A la vez, no faltaron algunos que veían en ellas unos sujetos útiles a la nación de las cuales no se podía prescindir 15 . Por tanto, el eco de las Luces no sólo se patentiza en la propuesta de Cortés al recomendar la instrucción de las indígenas, sino también al señalar su incorporación, por medio de la enseñanza, a un mundo de utilidad familiar y social.

\section{La idea providencialista de la historia}

El segundo punto por resaltar es la visión providencialista que se deja sentir en los informes del intendente y del arzobispo. Esa visión, por cierto muy occidental, estuvo intimamente ligada a una actitud filosófica y a una experiencia de fe que anidaron en el horizonte judeo-cristiano. Se partía, entonces, del ámbito cristiano-fideístico de un Dios creador como presupuesto básico para la explicación racional no sólo de la existencia del hombre y el mundo, sino además, de la misión o el fin que los designios divinos le tenían preparado a aquél. Se conjugaron la fe y la razón para creer y comprender desde la finitud humana el hecho mismo de la existencia de las cosas a partir de la nada, como también el lugar específico que el hombre ocupa en el cosmos y la historia. Este "providencialismo" tenía sus raíces en la visión hebrea de la historia: los acontecimientos humanos al tener un origen divino, poseen inevitablemente un fin, en cuyo caso dichos acontecimientos transcurren en un tiempo lineal. Pero, además, esa linealidad temporal se convierte en una perfecta historia de salvación, pues los hombres al proceder de la bondad creadora de Dios, deberán retornar a El16. De ese modo, la Europa cristiana se inundó de una conciencia providencial tanto ascética como combativa, que también quedó manifestada en el descubrimiento, conquista y coloniaje hispano-lusitano de América.

El cristiano-europeo tenía la convicción de haber sido elegido para el propósito que muy bien planteó Tomás de Aquino en el siglo XIII: “...el hombre ha sido ordenado por la divina providencia a un bien más alto de lo que puede su fragilidad experimentar en esta vida..." $17 \mathrm{De}$ acuerdo al aquinate ese bien superior significó el conocimiento o la contemplación de Dios dentro de un proyecto fundamentalmente vitalista que podía ser conseguido a través del cristianismo y que en cuanto tal, representaba para los bautizados un porvenir trascendente. Es así como la conciencia de "grandeza" que poseía el hombre por ser ente racional conjuntamente con la conciencia de haber sido elegido por un plan divino para la propagación de las virtudes cristianas, afirmaron y alimentaron durante muchos siglos la mentalidad occidental de un "optimismo providencialista".

Gutićrrez y Ulloa al realizar la descripción de los españoles en la Provincia de San Salvador, proyectó la convicción a la cual estamos aludiendo. Su análisis de contrastes no sólo lo llevó a enumerar los vicios de los demás grupos sociales, como las mentiras, la vagancia, embriaguez, escándalo o superstición; también fue consciente del peligro en el que se encontraba el "optimismo providencialista" por la degeneración de vida en la que había caído una gran parte de la "clase" española. A pesar de ubicarse en la cúspide de la pirámide social, una tercera parte de ellos corría la desafortunada suerte de perder "el lugar apreciable y distinguido á que la providencia los destinó en este suelo"18, debido al extravío de sus costum-

15. Ver Martín Gaite C., Usos amorosos del dieciocho en España, Madrid: Siglo XXI, 1972, pp. 203-230; Olaechea Labayen J.B., El mestizaje como gesta, Madrid: MAPFRE, 1992, pp. 77-82, 281-288; Domínguez Ortíz A., Hechos y figuras..., pp. 229-245. Abellán cita un fragmento de la obra El sí de las niñas del dramaturgo español del siglo XVIII, Leandro Fernández de Moratín, donde dice: "Ve aquí los frutos de la educación. Esto es lo que se llama criar bien a una niña: enseñarla a que desmienta y oculte las pasiones más inocentes con una pérfida disimulación. Las juzgan honestas luego que las ven instruidas en el arıe de callar y mentir.(...) Todo se les permite, menos la sinceridad (...) y se llama excelente educación la que inspira en ellas el temor, la astucia y el silencio de un esclavo." (Abellán J.L., op. cit., pp. 672).

16. Frost E. C., "La visión providencialista de la historia" en Robles L. (Coor.), op. cit., pp. 331ss.

17. Aquino T., Suma contra los gentiles, L. I, V, México: Porrúa, 1977, p. 6.

18. Gutiérrez y Ulloa A., Estado general de la Provincia de San Salvador: Reyno de Guatemala (Año de 1807), San Salvador: Dirección General de Publicaciones, 1962, p. 11. Gutiérrez y Ulloa, como intelectual orgánico de la Corona, no puede esconder el favoritismo sobre los de su clase; por ello divide a los españoles y criollos en los "de primer órden" y los de "condición común". En torno a los primeros dirá: "Además de los Empleados en 
bres. Si bien, Gutiérrez y Ulloa no es muy explícito con el término "providencia" dado que puede ser entendido en el sentido político o secular, como resolución o medida de la Corona o bien en el sentido religioso, como designio de Dios, dicha ambigüedad no impide estimar en el funcionario una visión providencialista, ya que ésta tal y como la concibieron los españoles era una fusión de elementos seculares y religiosos como enseguida veremos. Además, a pesar que este intendente, como cualquier funcionario de la Casa Borbón, fue leal representante de una dinastía que se caracterizó por su apasionado "regalismo", sobre todo en tiempos de Carlos III, no por ello se dirá que disminuyó o frenó su espíritu religioso ni que tampoco abandonó su conciencia providencial. Parte integrante y peculiar del espíritu ibérico fue la correspondencia entre los esfuerzos políticos con las intenciones evangelizadoras o simplemente religiosas. Es más, la legitimación de las dinastías borbónicas de Carlos III y Carlos IV se apoyaban en la teoría del derecho divino de los reyes. Teoría que sostenía, entre otros puntos, el agrado de Dios hacia los sistemas monárquicos.

Por eso, siguiendo la lógica de Gutiérrez y Ulloa, el lugar distinguido y honorable al que la providencia los había destinado en las tierras de ultramar no era más que continuar y ampliar la conducción de los acontecimientos político-religiosos iniciados desde el período del descubrimiento. Resultado de este fenómeno ideológico fue el arraigo del providencialismo en las mentalidades populares o religiosidad popular durante la colonia: la vida cotidiana, la vida íntima, los acontecimientos naturales y sociales dependían de la intervención providencial y de la relación de los creyentes con los designios divinos mediante una "fe providencialista y milagrera" 19.

A partir de esa conciencia de "puesto" o "lugar" que se ocupaba, gracias a los designios providenciales, se descubre una concepción de historia en donde, como ya se señaló, se entrecruzan elementos de fe y elementos políticos. En el interior de esa concepción se produjo un paralelismo entre la idea del puesto que el hombre ocupa en el cosmos - desde el momento de la creación- y la idea del puesto que el peninsular ocupa en tierras americanas. En ambos casos se tenía la convicción de poseer algo que había sido donado u otorgado y, por lo tanto, se debía cuidar, proteger o preservar porque se tenía una autoridad legítima sobre ello. Las dos ideas señalan un aspecto de carácter práxico-racionalista, pues, encontramos en la idea de "don providencial" un mundo donado por Dios a los hombres para que con su racionalidad cuiden de él y lo hagan su morada; en esa misma línea se aceptaba que los dominios americanos habían sido otorgados también por Dios para hacer con ellos el lugar preferente para la expansión de la fe cristiana. Los intereses políticos de la Corona al entremezclarse con los intereses evangelizadores configuraron un "mesianismo temporal" 20 que indudablemente sirvió más a los objetivos de la Corona que a los de la misma Iglesia. Dicho "mesianismo temporal" fue una combinación ideológica que mostró su eficacia y empuje en la conciencia colectiva hispánica durante el descubrimiento y la conquista de América y que ni los pensamientos más progresistas del siglo XVIII lo habían hecho desaparecer; al contrario, lo readaptaron a las circunstancias políticas de la época.

Ministerio Eclesiástico, Servicio del Rey, Administración de Justicia, y Oficios de República, se observa en los de primer órden, el mayor decoro y Patriotismo, mas todos sus esfuerzos no son suficientes á livertar una tercera parte de los de su esfera, perdidos en los escollos de una mala educación, y abandonadas costumbres" (p. 12).

19. Prien H-J., La historia del cristianismo en América Latina, Salamanca: Sígueme, 1985, pp. 294-295.

20. Dussel E., Historia de la Iglesia en América Latina, Barcelona: Editorial Nova Terra, 1972, p. 54; Prien H-J., op. cit., pp. 58 y 68; Florescano E., "Concepciones de la historia" en Robles L. (Coor.), op. cit., pp. 316ss; Konetzke R., op. cit., pp. 26ss. 
En los tiempos de la conquista, el providencialismo quedó explícito en documentos de diversa índole como en el tan discutido Requerimiento, que justificaba la concesión papal $-\mathrm{y}$ por ende, la concesión divina- de estas tierras para poder realizar en ellas la pretendida historia de salvación. Dicho documento debía leerse a los poblados indígenas para que éstos depusieran sus armas y se sometieran a la corona española como legítimos vasallos 21 . Más tarde, el pensamiento tradicional español del siglo XVIII continuó con la misma sustentación teórica, aunque ahora el acento recaía en la defensa de los ideales e idiosincracia netamente ibéricos frente a las concepciones ilustradas que representaron para los apologistas de la tradición, la injerencia de ideas foráneas y dañinas a la vida nacional. La misión del Estado español seguiría siendo, desde esta perspectiva, la construcción de un orden político universal basado en el servicio a Dios y al catolicismo. Y realizar tal empresa significaba reinvindicar la esencia hispánica o el "Ser español"22. Por su lado, la ilustración española no despreció en absoluto la idea providencialista. De alguna manera quedó adaptada a la fundamentación del Despotismo ilustrado borbónico, sobre todo cuando se afirmaba que el rey, al tener su poder un origen divino, se convertía en un verdadero "vicario de Dios" y, por lo tanto, revestido con legítimos derechos sobre los asuntos civiles y eclesiales 23 .

Quizá de los dos documentos estudiados, el de Cortés y Larraz muestra un "optimismo providencialista" con mayor esclarecimiento. Veamos como lo expone en el prólogo de su informe: "To- dos saben las santas providencias que el católico celo de nuestros monarcas ha tomado para la felicidad de estos Reinos, desde el principio de su conquista; principalmente para plantar, radicar y perfeccionar en ellos la sagrada religión de Jesu-

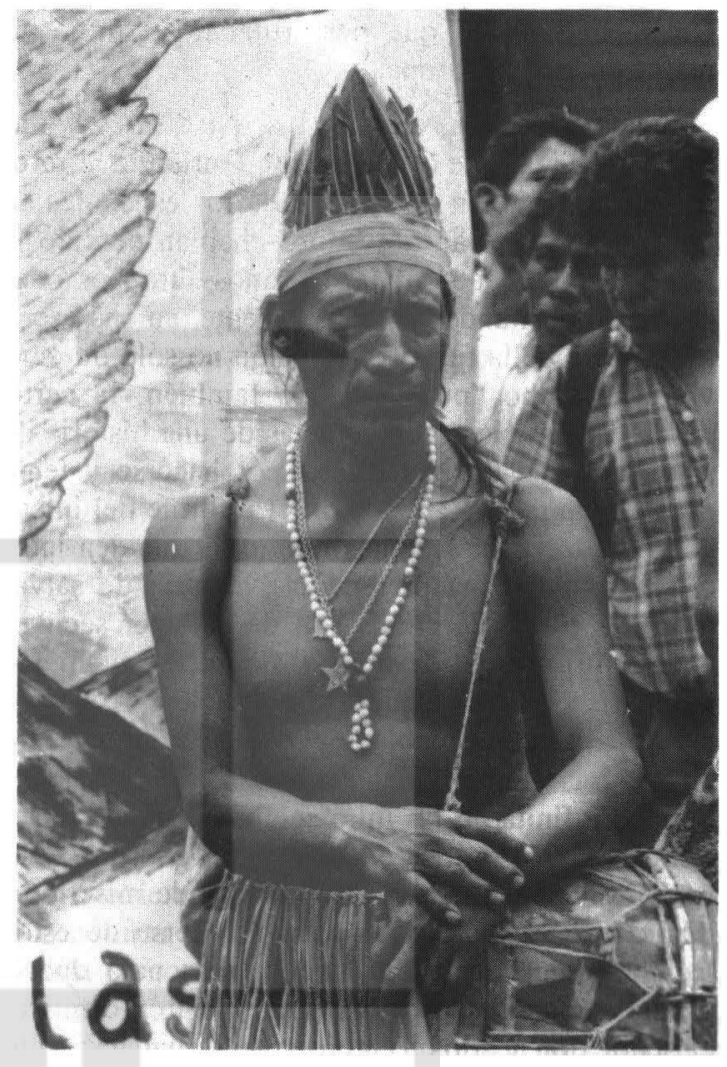

21. Ver Hanke L., La lucha española por la justicia en la conquista de América, Madrid: Aguilar, 1967, pp. 63ss., 253ss., Mires F., La colonización de las almas. Misión y conquista en hispanoamérica, San José: DEI, 1987, pp. 48-58. Parte del texto del Requerimiento decía: "De parte del Emperador y Rey don Carlos, y doña Juana, su madre (...). Sus criados os notificamos y hazemos saber, como mejor podemos, que Dios nuestro scñor, uno y cterno, crió el ciclo y la ticrra, e un hombre e una muger, de quicn nos c vosotros y todos los hombres del mundo fueron y son descendientes e procreados (...).De todas estas gentes Dios nuestro señor dio cargo a uno, que fue llamado S. Pedro, para que de todos los hombres del mundo fuesse scñor y superior a quien todos obedeciesen (...). Uno de los Pontífices pasados que en lugar deste succdió en aquella dignidad y silla que he dicho, como señor del mundo hizo donación de estas islas y tierra firme del mar Océano a los dichos Rey y Rcyna e sus sucessores..." (Pereña L., La idea de justicia..., pp. 237-238).

22. Puy F., El pensamiento tradicional en la España del siglo XVIII (1700-1760), Madrid: Centro de Estudios Constitucionales, 1966, pp. 97, 124-125, 130-142. Sobre algunos representantes del pensamiento tradicional español y su reacción ante las ideas ilustradas ver Menéndez Pelayo M., Historia de los heterodoxos españoles. T. II, Madrid: BAC, 1956, pp. 666-714.

23. Ver la fundamentación de Campomanes al Despotismo ilustrado borbónico en Prieto F., op. cit., pp. 450-454. 
cristo, sin la que no puede haber verdadera felicidad"24. Hasta aquí puede observarse que se sigue manteniendo la combinación ideológica entre la misión política y la misión evangelizadora. Sin embargo, el arzobispo no ocultó el estado moral de los habitantes de su diócesis: los vicios, los desórdenes, la impiedad reinaban por todas partes. Unas condiciones que desvirtuaban el proyecto realizado por la Corona.

Todo apuntaría, entonces, a que Cortés y Larraz - al igual que el intendente Gutiérrez al referirse a la situación deplorable de los españoles en la Provincia de San Salvador- habían perdido la fe en el lugar que como cristianos-europeos ocupaban en el mundo; pero, realmente, en sus escritos se percibe la fuerte convicción no sólo de reinvindicar dicho "puesto", sino también, la certidumbre de ser los protagonistas de una historia de salvación que todavía estaba por hacerse y tenía mucho que dar. $Y$ aunque en el informe del intendente no haya expresiones religiosas que den indicio alguno de una pretendida "historia de salvación", pues sus términos son de carácter secular, en el informe del arzobispo sí queda netamente explícito. El afirma que esa condición irreligiosa continuaría en la población de estas regiones si "Dios por una providencia muy particular de su bondad infinita no las mira según su grande misericordia". "No omito (...) decir aquí que no faltan preludios bien fundados de esta grande misericordia, con que Dios quiere compadecerse de estos Reinos y que no dejan fundamentos para dudar, mirando el corazón de nuestro monarca calólico, el señor don Carlos Tercero, en el cual habiendo puesto Dios con tanta liberalidad tal abundancia de virtudes para reinar sabia y felizmente y sacrificándolas con la atención que ni se oculta ni puede ocultarse a la felicidad de estos Reinos que (...) mira con otra especialidad que a lo restante de sus dominios, sea en su dichoso Reinado (...) el tiempo feliz que destinó su alta providencia para que cesen en la América sus ofensas, para que se acabe el desorden, para que reine la virtud y domine la religión" 25 .
El arzobispo es muy claro. El reinado de Carlos III lo presentó como el tiempo histórico donde, por designio de Dios, se emprenderá una praxis de reconstrucción moral de los vasallos. De esa forma, el conocimiento de los vicios de los "otros" -incluso, de muchos peninsulares - llevó al eclesiástico a autoafirmar la conciencia del destino histórico de su monarca, de su reino y de él mismo. Con ello, Cortés está también apuntando a un explícito "regalismo", es decir, a una ideología monárquica que estipulaba como normal la intromisión del poder político en los asuntos eclesiales. Lo cual no significó por ningún motivo la pérdida de religiosidad en el interior de la Corona; más bien, en términos prácticos, significó la realización más plena del "mesianismo temporal" que llevaría a cabo el régimen ilustrado ibérico26.

Después de todo, lo que puede desprenderse de ámbos informes es lo siguiente: dado que un numeroso grupo de peninsulares vivía sumido en la ignorancia y la vida licenciosa, el protagonismo de esa historia nacional-religiosa en América quedaba en manos de los funcionarios de la Corona y de la jerarquía eclesiástica que, a juicio de ellos mismos, sí vivían con la mayor honorabilidad y patriotismo.

\section{Racionalidad utilitarista y entorno natural}

El último punto es el de la visión utilitaria con la cual fue visto el entorno natural de las posesiones coloniales salvadoreñas. En algunas ocasiones se ha creído que la misión ibérica en tierras de ultramar se redujo meramente a la incorporación de los pueblos naturales al orden cristiano, diferenciándose de los sistemas colonizadores realizados por los otros pueblos europeos, para quienes lo más importante fue la conquista material o el aprovechamiento de la riqueza de los suelos americanos 27 . Tal vez ha llevado a pensar lo anterior el marcado carácter religioso de las empresas ibéricas - apreciado en el punto precedente-, como también la mentalidad señorial que continuaba con

24. Cortés y Larraz P., Descripción geográfico-moral de la diócesis de Goathemala. T. I, Guatemala: Biblioteca "Goathemala" de la Sociedad de Geografía c Historia de Guatemala, Vol. XX, 1958, p. 11.

25. Ibid., p. 11.

26. Sobre más pistas del regalismo de Cortés y Larraz, ver sus cartas en las que manifiesta haber recibido la Real Cédula del 15 de septicmbre de 1774 (pp. 8-12) en Montes S., Etnohistoria de El Salvador. El guachival centroamericano. T. II, San Salvador: Ministerio de Educación, 1977.

27. Zea L., Filosofia de la historia americana, México: FCE, 1978, pp. 105-106, 115-116, 134-136. 
profunda vigencia en la cosmovisión y las relaciones sociales españolas aun a finales del siglo XVIII y principios del siglo XIX. A través de una limpieza de sangre o a través del éxito por medio de actividades industriosas, hispánicos de distintas esferas sociales buscaban ansiosamente obtener honor, status, perpetuación de la grandeza familiar e individual28. Ese decoro y búsqueda de distinción nobiliaria, de puestos distinguidos, de hidalguía, respetabilidad o reconocimiento de los demás fue una constante muy arraigada en la Península y América, inclusive por muchos ladinos y criollos. Basta observar en las Memorias del arzobispo de Guatemala, Francisco de Paula García Peláez (siglo XIX), la operatividad de esta mentalidad en tierras centroamericanas. Concretamente lo que opinó el deán García Redondo en un discurso sobre el fomento de las cosechas de cacao (1799): “...el indio ha sido y aun es el único agricultor de nucstras Américas. El español ni puede ni tiene necesidad de serlo (...). El ladino mira como propio del indio el manejo de la hazada, y no se cree nacido para doblar las costillas; sin embargo que no dejan de verse algunos (...) españoles europeos aplicarse á la agricultura con éxito..."; fijémonos que el español, aunque en ocasiones se vio forzado al trabajo agrícola, a opinión del deán, no le era dable una condición semejante; por otro lado, la actitud que describe sobre el ladino es vista, más adelante, por García Redondo como "una mal fundada y ridícula presunción caballeresca" 29 .

Con todo, no es cierto que España se haya lanzado a una empresa meramente evangelizadora. De hecho, el "mesianismo temporal" desmiente dicha aseveración al haber mostrado compatibles los intereses temporales de la Corona - cuando se extrajeron materias primas y metales preciosos,

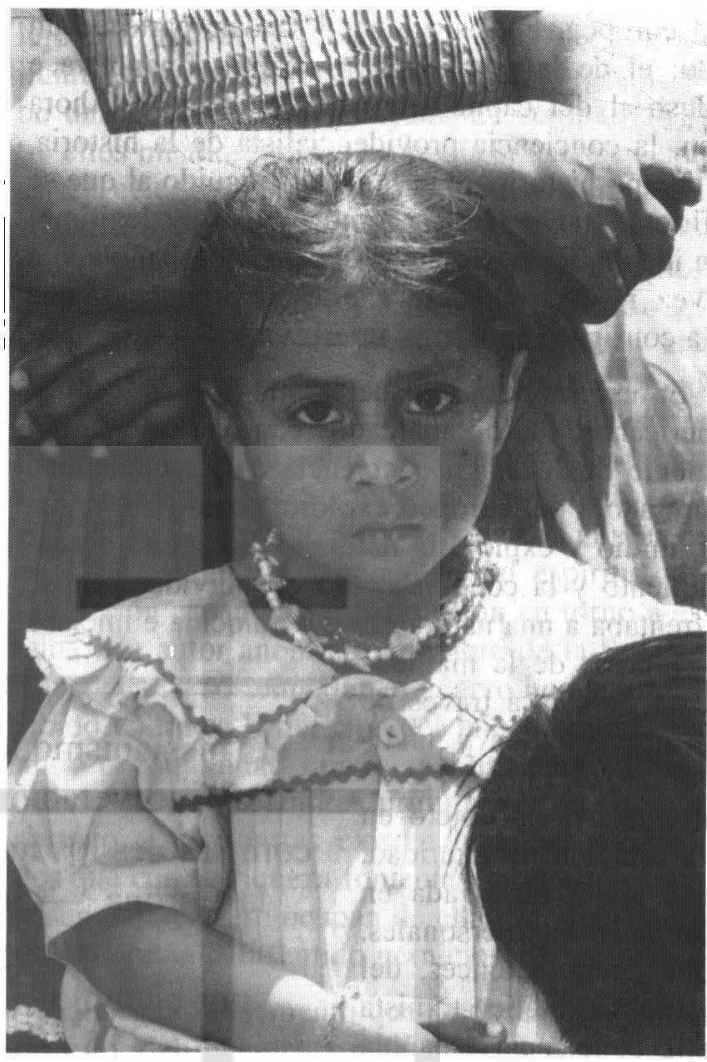

por ejemplo-, con los intereses evangelizadores. Esta "doble misión" del imperio español durante la conquista y coloniaje no debe verse en forma aislada como un caso individualista o excepcional de avidez de poder, gloria y enriquecimiento. Ello sería llevar la controversia, apuntada al inicio de este apartado hacia el otro extremo. Mas bien, habría que indicar que el escenario donde se movía la misión española era el de la expansión comer-

28. Domínguez Orlíz nos dice: "La famosa real cédula de $18 \mathrm{dc}$ marzo de 1783 (...) declarando honestas todas las profesiones y abriendo la posibilidad de ennoblecimiento a la familia que durante tres gencraciones hubicre mantenido un cstablecimiento industrial o mercantil de notable utilidad pública fue (...), la concesión máxima de la monarquía ilustrada" (Sociedad y Estado..., pp. 353). Para este historiador español, fue en la época de los Borbones (s. XVIII-XIX) cuando la teoría tradicional de la nobleza como herencia biológica o transmisión heredilaria de ciertas virtudes, si bien no desapareció por completo, al menos cedió terreno a una concepción más versátil cifrada en el reconocimiento público de la ascención social, en el reconocimiento del éxito, el mérito individual y cl trabajo. (ver ibid., pp. 354; Dominguez Orlíz A., Hechos y figuras..., pp. 201-202; lambićn Sarrailh J., op. cit., pp. 526-527).

29. García Peláez F. de P., Memorias para la historia del Antiguo Reyno de Guatemala, T. III, Gualemala: Establecimiento tipográfico de L. Luna, 1852, pp. 188, 19]. Por su parte, Isabel Casín al referirse sobre los hacendados españoles en América, en su obra La hacienda colonial. Una contribución a la historia económica de El Salvador, San Salvador: Ministcrio de Educación, 1972, dicc: "Generalmente inculto y no perteneciente a la nobleza, pero con el afán de conseguir en breve ticmpo más la nobleza comprable que la riqueza misma, cl hacendado ha heredado el patrón del sistema de adquisición de nobleza tradicional en España desde la Reconquista, que fue trasplantado a América..." (p. 15). 
cial europea. Fue, sin lugar a dudas, parte de un todo: el de la revolución mercantil, financiera e industrial del capitalismo de Occidente 30 . Ahora bien, la conciencia providencialista de la historia, el tiempo histórico y el lugar distinguido al que se refirieron tanto Cortés como Gutiérrez, legitimaron ideológicamente dicha expansión española $\mathrm{y}$, a la vez, reforzaron las relaciones de producción que ésta configuró en tierras americanas.

En ese sentido, los suelos americanos, centroamericanos, fueron abarcados con una mirada netamente dualista. La conciencia o la racionalidad escrutadora del europeo exploró, cuantificó, registró, midió y explotó la naturaleza desde el descubrimiento y la conquista. Era el individuo que se enfrentaba a una naturaleza desconocida e iniciaba la empresa de la manipulación de ésta a través de distintos medios y tácticas. Era el sujeto que se enfrentaba a su objeto en otra relación de alteridad, hasta ahora observada en relaciones interpersonales. ¿Qué decir, entonces, del legado aristotélico-tomista en la conciencia española sobre la superioridad de los saberes especulativos con respecto a las ciencias, artes o capacidades prácticas? ¿Fue acaso dicha mentalidad un obstáculo para la conciencia dual entre individuo-naturaleza? Parece que no. Si bien el espíritu nobiliario español apostó durante mucho tiempo por ese legado que se traducía en la superioridad del linaje sobre las tareas manuales, ello no negó la relación dualista tanto en Europa como en América entre conciencia y entorno, entre observadores y observados o, si se quiere, entre sujeto explotador y naturaleza explotada. De ese modo, la riqueza extraída de los suelos por me- dio de los vasallos y la posesión. de los vasallos mismos otorgaba honor, proporcionaba el respeto de los otros y conseguía un ascenso a una posición señorial. Lo cual no quitaba que aquéllos carentes de fortunas y vasallos buscasen su pretendida hidalguía con el esfuerzo propio o perpetuando su apellido al vincularlo a los pocos bienes poseídos $^{31}$. Por lo que el trabajo a costa de otros (vasaIlos, indígenas, peones, ladinos...) que beneficiaba a los señores o hacendados o el trabajo realizado con los propios esfuerzos, pero con muchas penurias, se constituyeron en medios para alcanzar la honorabilidad.

La idea utilitaria de la naturaleza y el fomento de investigaciones que permitieran comprender lo útil que podía ser el entorno si era bien examinado o aprovechado a través de métodos más empíricos y menos especulativos, fue la persistente preocupación de los ilustrados españoles como también de las Sociedades económicas Amigos del País. Se demandaba al Estado la prosperidad de la nación $\multimap$, en términos iluministas, su felicidadmediante el incentivo de las ciencias, las artes productivas, la libertad al comerciar, la imposición de restricciones a los privilegios de la Iglesia y de límites a las propiedades eclesiásticas, entre otros aspectos. Pero, en realidad, el desarrollo del país se cifraba, de acuerdo con los ilustrados, en el desarrollo eficiente de la agricultura juntamente con la industria y el comercio - programas con alcances directos a las colonias-, y no en la extracción de metales preciosos tal como habían sido los intereses económicos durante los siglos anteriores (intereses que estuvieron

30. Kaplan M., Formación del Estado nacional en América Latina, Bucnos Aires: Amorrortu, 1976, pp. 65-66.

31. Domingucz Ortíz afirma que durante el siglo XVIII, los gremios españoles, hasta aquéllos de profesiones humildes, buscaban la distinción social: "Todo cl mundo quería pertenecer a un círculo distinguido y sclecto. ¿Cómo podía lograrse csto en una socicdad que apreciaba poco los trabajos manuales? Estableciendo categorías dentro de ćstos y una reglamentación propia para hacerlos cstimables; una reglamentación que dificulte el ingreso, scleccione los candidatos y cleve su nivel de considcración social, que entonces era tan buscado..." ( Sociedad y Esıado..., p. 388-389, 431). La vinculación del nombre a biencs mucbles o inmucbles a perpetuidad y que sc transferían a un heredero único sc conoció como "mayorazgo". Ver Carr R., España I808-1939, Barcelona: Aricl, 1978, pp. 52-56; Domíngucz Ortíz A., Sociedad y Estado..., pp. 328-329. 
a la base del desarrollo monetario de la Europa postrenacentista y de las transformaciones sociopolíticas de sus Estados) ${ }^{32}$. Dichas actividades producirían riqueza y, a la vez, éxito que podía traducirse en hidalguía individual o colectiva. Así, los ilustrados españoles despejaron el cariz peyorativo que anteriormente envolvía el término "utilidad" para incorporarlo sin reservas ni prejuicios a un sistema reformado de vida propuesto por ellos. El término "utilidad" cobijaba, entonces, no sólo a las denominadas "ciencias útiles" en contraposición a las "estériles asignaturas escolásticas", sino también a todos aquellos oficios mecánicos y manuales, con larga tradición de desprecio, pero que a partir de ese momento quedaban libres de todo estigma y destinados para el beneficio social. Por lo visto, la profunda estimación de lo útil como en años anteriores lo había reconocido Descartes con aquellas ciencias más valiosas que convertían a los hombres en señores de la naturaleza o como lo había reconocido Hume en tanto que era un criterio de las normas morales, llegó de distintas fuentes a España y los novatores e ilustrados la adaptaron a las necesidades del reino para acrecentar el progreso humano a una con el progreso material.

El informe del intendente Gutiérrez y Ulloa revela elementos de la mentalidad ilustrada cuando valora las posesiones coloniales de la Provincia de San Salvador: "Su terreno volcánico (...) proporciona las más alagüeñas perspectivas y situaciones, facilitando, con la variedad de temperamentos, (...) quanto pudiera apetecerse en paises mas sociables para satisfacer las comodidades de la vida, excitar el lujo fomentador y extender los progresos de las Artes, yndustria y Comercio..."33 Dos elementos saltan a la vista en la anterior descripción del intendente. El primero de ellos está referido a la utilización de la naturaleza para satisfacer las comodidades y el lujo. La temática del lujo fue una de las más peculiares de la época iluminista y de los ilustrados. Sin embargo, no hubo una posición homogéneamente compartida entre ellos mismos, pues bien podía situarse su análisis en el campo político, económico, hedonista o social. Lo mismo ocurrió fuera de los mencionados círculos. Para unos, más cercanos a la moral de la Iglesia, el lujo se presentaba contrario a la vida virtuosa o algunos menos practicantes y críticos de las Luces, como Rousseau, creyeron que era una manifestación de la decadencia social; para otros, constituía una consecuencia del progreso económico. Las Sociedades Económicas Amigos del País (la primera fue fundada en Guipúzcoa en 1764), en tanto exponentes del espíritu de la ilustración española, se expresaron en torno a este tema. Un autor anónimo, miembro de la Sociedad Vascongada, sostenia que el género humano ha recibido enormes beneficios del lujo porque le permitió la comodidad, con la cual ha venido diferenciándose de los hombres primitivos. Más tarde se sostuvo que mientras existan hombres acomodados que con su riqueza fomentasen las artes y ayudasen a quienes se ocupan de ellas, la lujosidad no tendría ya ningún sentido pernicioso ${ }^{34}$.

El segundo elemento que se observa en la descripción del intendente es la idea de fomentar las artes, la industria y el comercio. Nada más cercano a una idea pragmática de la naturaleza que aquélla en la cual se estimula a la sociedad para aprovechar los recursos naturales con todos los oficios y las tareas útiles que ennoblecen a los individuos y hacen prosperar a las naciones. Ese fue el trasfondo de las innumerables apologías ilustradas en favor de las artes, la industria y el comercio. Por ello, la finalidad de las Sociedades Económicas españolas quedaba esclarecida con el objetivo programático de la Sociedad Vascongada: "fomentar, perfeccionar y adelantar la agricultura, la economía rústica, las ciencias y artes, y todo cuan-

32. "La teoría económica del mercantilismo mantenía desde hacía mucho liempo, que la riqueza de una nación se medía por la cantidad de metales preciosos que poseía". "Bajo Carlos III, los escritores que abandonaban su fe en el oro y la plata de América, para abogar por una cconomía agrícola y comercial vigorosa, dirigida por el rey, formaban legión" en Herr R., España y la revolución del siglo XVIII, Madrid: Aguilar, 1971, pp. 39 y 41; Murillo F., "Las Indias y el cambio económico en la España del siglo XVIII. Administración y comercio" en AA.VV., La América española..., p. 19. También Sarrailh J., op. cit., pp. 546-552.

33. Gutiérrez y Ulloa A., op. cit., pp. 9-10.

34. Ver Sarrailh J., op. cit., pp. 243-245. Debemos recordar que las Sociedades Económicas españolas fueron herederas de las diversas Sociedades literarias, artísticas, científicas y económicas que ya existian en países como Inglaterra y Francia. Ver sobre estas Sociedades en Mason S., Historia de las ciencias 2. La revolución cientifica de los siglos XVI y XVIII, Madrid: Alianza Editorial, 1990, pp. 172-185. 
to se dirige inmediatamente a la conservación, alivio y conveniencias de la especie humana"35. Por lo visto, el eclecticismo ilustrado español en el campo social y político navegó también en el ámbito económico. La fascinación por las ideas fisiocráticas $\longrightarrow$ hablando en términos generales, la confianza en el agro como fuente de riqueza de un Estado- no debilitó la atención hacia el comercio y el interés por potenciar las industrias rurales. Lo que hubo, entonces, fue una perfecta combinación de todos estos rubros, constituyendo así una particular visión utilitaria y diversificada de la naturaleza.

La mirada analítica de Gutiérrez descubrió las ventajas naturales que ofrecía esta Provincia al sistema colonizador, a pesar de encontrarse esta última en una zona geográfica distante para las rutas comerciales. La fertilidad de sus suelos y los productos que de ellos se extraían significaron para el funcionario y, en general, para los hacendados peninsulares y criollos, su propio enriquecimiento y la contribución al sostenimiento de estructuras de poder familiar y administrativas. No sólo se configuró una economía con miras a satisfacer y sujetarse a las demandas de la metrópoli o de los mercados internacionales, sino también se reforzaron las instituciones coloniales (repartimientos, encomiendas, etc.) con las que se aseguraría el trabajo de los indígenas ${ }^{36}$. Sin embargo, el intendente se lamentó de una serie de inconvenientes que podrían convertirse en enormes dificultades para el desarrollo de esta región -inconvenientes, claro está, que afectarían a los intereses del sistema colonizador en Centroamérica. Los obstáculos aludidos fueron la insuficiente fuerza laboral en el campo agrícola y mecánico, la deficiente y atrasada educación, la "débil clase de sus Pobladores", el desorden civil. Además, el funcionario no veía con buenos ojos el que la industria rural quedara reducida al cultivo del añil, el maíz y la cría de ganado, cuando existía una variedad de recursos aprovechables como ríos, minas, aguas minerales, granos, maderas, cacaos, que los hacendados ha- cían todo "este conjunto de circunstancias poco útiles"37. La preocupación del intendente por la diversificación de la industria rural era una opinión compartida en la Capitanía General por los funcionarios reales y la Sociedad Económica de Guatemala ante la crisis de precios que había experimentado el añil a finales del siglo XVIII. No es, pues, ninguna coincidencia o casualidad que los inconvenientes apuntados por Gutiérrez y Ulloa hayan sido compatibles con las demandas hechas a la Corona por la élite de ilustrados españoles durante ese tiempo. Es que, en realidad, primaba en estos intelectuales orgánicos el deseo de perfilar un nuevo rumbo del Imperio ante las transformaciones político económicas que sufría Europa a pasos muy rápidos.

Tanto los ilustrados españoles como los liberales ibéricos—quienes surgieron a finales del siglo XVIII con la denominada "Escuela iluminista de Salamanca" y que algunos tendrían una participación destacada en las Cortes de Cádiz- demostraron su preocupación por tales circunstancias. Los primeros, manteniendo un espíritu ecléctico entre el mercantilismo, la fisiocracia y el liberalismo, ponían su confianza en la Corona como eje indispensable para resolver los males del reino; los segundos -en donde podemos situar a José Ibáñez de la Rentería, León de Arroyal y Francisco Cabarrús-, confiaban en una felicidad social y económica a través del constitucionalismo, la división del poder político, la idea de ciudadanía, la idea de Estado limitado, entre otros puntos. Ambos grupos eran deudores de pensadores extranjeros, entre los cuales figuraban: Locke, Mostesquieu, Hume, Smith, Condillac, Mirabeu, Voltaire, Beccaria, Quesnay, etc., y de la idea utilitarista de la naturaleza de la cual estaba impregnada Europa desde hacía mucho tiempo; sin embargo, como rápidamente hemos visto, concibieron sus propuestas de manera distinta 38 .

La preocupación y el interés pragmático del intendente por las posesiones coloniales de la Pro-

35. Abellán J.L., op. cit., pp. 734.

36. Palma Murga G., "Economía y sociedad en Centroamérica (1680-1750)" en Pinto Soria J., (Edit.), Historia general de Centroamérica. El régimen colonial (1524-1750),T. II, San José: FLACSO, 1994, pp. 251-254; Colindres E., "Períodos de la historia económica de El Salvador" en ECA, No 329, marzo, 1976, pp. 89-98.

37. Gutiérrez y Ulloa, A., op. cit., pp. 10. La cursiva es nuestra. Sobre más referencias de la idea utilitarista del intendente en la Provincia, pueden verse las siguientes páginas de su informe: 23, 34, 46, 49, 57, 64, 75, 79.

38. Abellán J.L., op. cit., pp. 843-860; Herr R., op. cit., pp. 41-72. 
vincia bajo su jurisdicción quizás queden contextualizados con la siguiente postura de Jovellanos, para quien los conceptos de gloria y triunfo no significaban los pilares del progreso de un Estado. Jovellanos afirmaba en 1785 que "todo es ya diferente en el actual sistema de Europa. El comercio, la ilustración y la opulencia, que nace de entrambos, son y probablemente serán por largo tiempo, los únicos apoyos de la preponderación de un estado, y es preciso volver a éstos el objeto de nuestras miras, o condenarnos a una eterna o vergonzosa dependencia, mientras nuestros vecinos libran su prosperidad sobre nuestro descuido" 39 .

Es interesante observar que dos de los obstáculos aludidos por Gutiérrez - insuficiente fuerza laboral y atrasada educación - fueron también los puntos recriminados por pensadores como Jovellanos ante el deficiente progreso español, comparado con el caso de Inglaterra o Francia. Los ilustrados veían que la nobleza y el clero ibérico constituían un impedimento mientras siguieran formando un gran porcentaje de la población activa masculina y concentraran en sus manos extensas propiedades pobremente aprovechadas 40 . En torno a la "atrasada educación" ya tuvimos la oportunidad de mirar rápidamente en el primer apartado cuál fue la postura de este minúsculo grupo de ilustrados ante el estado deplorable de la mayoría de la población en la Península. Ahora bien, sería falso pensar en este punto que los hechos que llevaron a advertir dichos obstáculos, tanto por los ilustrados españoles como por Gutiérrez, hayan sido los mismos. No lo fue así. Mientras las críticas a la improductividad de un recurso humano confinado en el clero y la nobleza era una constante en la Península, la "insuficiente fuerza laboral" en la Provincia de San Salvador a la que se refería el intendente obedecía a tres causas fundamentales: la primera, por la concepción antropológica de "holgaza- nería" tenida hacia el indígena, el ladino y hasta de españoles (criollos o peninsulares), tal como ya se apuntó; la segunda, por la escasa población en la zona a diferencia de otras regiones del Imperio; la tercera, por la deserción de muchos naturales de sus lugares de trabajo, así como también por su anonimato en los registros parroquiales para burlar el pago de impuestos o la contribución a las cofradías y curatos.

Ciertamente esta tercera causa tenía sus particulares motivos. La racionalidad utilitarista del régimen colonial había convertido a los indígenas en instrumentos de producción. La mano de obra de éstos fue indispensable para los cultivos de cacao, bálsamo, alimentos, etc., que sirvieron para la exportación, el consumo interno y para la manutención del sistema burocrático colonial en Centroamérica. Posteriormente, el cultivo del añil significó el afianzamiento de la propiedad privada española: la hacienda, y con ella la continuación de métodos degradantes para con los naturales que Irabajaban en dichas propiedades; nada más que ya entrado el siglo XVIII, la labor de aquéllos contaba con la aprobación explícita de la Corona. En efecto, en 1737, los borbones eliminaron la prohibición de utilizar el trabajo indígena en las haciendas añileras, prohibición que había sido impuesta desde el siglo XVI41. Esta estructura monocultivista del añil en la Provincia de San Salvador -criticada por Gutiérrez y Ulloa- permitió, asimismo, un lento e inexorable proceso de mestizaje al ser absorbidas las comunidades indigenas por la actividad económica que demandaban las haciendas. Por lo que las intenciones del arzobispo Cortés y Larraz sobre un proceso de ladinización mediante la cultura y los matrimonios interraciales, mediatizados también por la educación, tuvieron mayor eficacia y se vieron favorecidos a través de la racionalidad utilitaria que el régimen colonial impuso.

39. Citado en Abcllán J.L. op. cit., pp. 553.

40. Carr R., op. cit., p. 52. Carr sosticne que los datos de un censo de 1797 revelaban que la nobleza y el clero poscían por mayorazgo o manos muertas las dos terceras partes de la licrra de España, lo que impedía un desarrollo económico de esta nación comparado con sus vecinos.

41. Solórzano J.C., "Los años finales de la dominación cspañola (1750-1821)" en Pérez Brignoli, H., (Edit.), Historia general de Centroamérica. De la llustración al liberalismo, T. IIJ, San Josć: FLACSO, 1994, pp. 2225; Browning D., El Salvador. La tierra y el hombre, San Salvador: Ministerio de Educación, 1975, pp. 76-233; White, A., El Salvador, San Salvador: UCA Editores, 1996, pp. 27-54; Smith, R., "Producción y comercio de añil en la Guatemala colonial" en Cáceres L.R., (Edit.), Lecturas de historia centroamericana, San Josć: Banco Centroamericano de Integración Económica, 1989, pp. 141-149. 
Con todo lo dicho hasta ahora podría decirse que la sociedad colonial salvadoreña, como la hispanoamericana en general, no fue un sistema caracterizado solamente por la inhibición o los modos represivos e intimidantes, extendidos a todo el cuerpo social. De ello, quizá el caso más representativo habría de buscarse en las relaciones de producción. En realidad, las prácticas de la sociedad colonial fueron más allá de una sintomatología típicamente represiva o sancionadora. El análisis sobre la vida de los distintos grupos sociales y sus diversas manifestaciones cobraron un interés especial por parte del poder político, y los mecanismos utilizados en el análisis del "otro" contribuyeron en la producción de una serie de teorías o discursos que formaron una novedosa antropología en la cual el ibero confirmaba su conciencia de sí.

Es interesante la figura que Foucault ha utilizado - tomada de Jeremy Bentham - para referirse a una estructura sociopolítica de carácter omnividente. Esta figura ha sido el panóptico42. ¿Puede sostenerse que en la época colonial salvadoreña y en general, latinoamericana- existió un panoptismo social? Ciertamente que no tal y como lo analiza este autor francés. Sin embargo, puede hablarse análogamente de un panoptismo ejercido por la Corona, a través de sus funcionarios tanto políticos como eclesiásticos. Demás está decir que el mencionado panoptismo - si es que se quiere utilizar esta figura - no sólo posibilitó el conocimiento de los otros, como la mejor manera o el mejor medio para concentrar, clasificar, analizar y vigilar a los individuos, sino también posibilitó su sometimiento.

En nuestro caso, los informes del arzobispo y del intendente han sido lo bastante claros para sostener que a finales de la época colonial, en lo que actualmente es el territorio salvadoreño, se realizó un proceso de autoafirmación de la conciencia ibérica a través del análisis y de la clasificación de los otros y de los recursos naturales. Esa "conciencia de sî" implicaba, en consonancia con el espíritu de la época, un reconocimiento de la racionalidad del indígena, a pesar de sus vicios y defectos, como también, sus procesos de encauzamiento a través de la cultura; implicaba, además, el ethos histórico que desempeñaban los funcionarios en estas tierras; asimismo, el ethos práctico para extraer las máximas utilidades de la naturaleza.

Como hemos visto, con Cortés y Larraz y con Gutiérrez y Ulloa no nos encontramos con dos filósofos. Ni tampoco en sus informes asistimos a dos escritos sistemáticos sobre la conciencia ibérica a finales del período colonial salvadoreño. Pero eso no importa, pues la mayoría de las ideas ilustradas españolas no proceden de obras sistemáticas, sino más bien de informes, proyectos, planes, memorias, etc., dado que la concepción de literatura adquirió en ese momento un carácter más amplio porque se intentaba socializar el ámbito cultural de una manera profusa 43 . Tal vez ahí estriba la originalidad, riqueza y amplitud del pensamiento ilustrado hispánico que algunos criticarían como fragmentario y disperso. De cualquier forma, la intención de este trabajo ha sido reconstruir algunos elementos con los cuales sea posible hacerse una idea esbozada de la conciencia social ibérica en aquélla época. Tener presente esa conciencia social resulta valioso para una historia del pensamiento, porque dejó una enorme huella en la formación progresiva de la mentalidad criolla y popular, como también para una historia de las corrientes filosóficas.

42. Ver Foucault M., Un diálogo sobre el poder, Madrid: Alianza edilorial, 1994, pp. 59-72. Tambićn del mismo autor: Vigilar y castigar. El nacimiento de la prisión, Mćxico: cditorial Siglo XXI, 1990, pp. 139- 230.

43. Abcllán J.L., op. cit., pp. 484-485. 